\title{
sciendo
}

\section{The impact of formal and non - formal education on youth employability in Bosnia and Herzegovina}

\author{
Amila Pilav-Velić \\ School of Economics and Business, University of Sarajevo, \\ Bosnia and Herzegovina \\ amila.pilav-velic@efsa.unsa.ba \\ Hatidža Jahić \\ School of Economics and Business, University of Sarajevo, \\ Bosnia and Herzegovina \\ hatidza.jahic@efsa.unsa.ba \\ Jasmina Okičić \\ Faculty of Economics, University of Tuzla, Bosnia and Herzegovina \\ jasmina.okicic@untz.ba \\ Meldina Kokorović - Jukan \\ Faculty of Economics, University of Tuzla, Bosnia and Herzegovina \\ meldina.kokorovic@untz.ba
}

\begin{abstract}
Education plays a central role in today's understanding of growth and development dynamics. However, its relationship with other factors is complex. This paper aims to investigate the effect of different forms of education on youth employability in Bosnia and Herzegovina. This is done by using the USAID MEASURE - BiH National Youth Survey. Research has shown that formal education and non-formal education through internship programmes, volunteering, paid jobs other than internships are significant predictors of youth employment status. The study also has several implications for academics and practitioners since it provides new insights into both employment patterns and practices in one transition economy but also calls for further analysis of the link between education, formal and non-formal, and youth employment.
\end{abstract}

Keywords: education, employment, logistic regression, youth.

JEL classification: $\mathrm{C} 1,120$.

DOI: 10.2478/crebss-2019-0006

Received: December 05, 2018

Accepted: April 09, 2019

\section{Introduction}

Education has a central role in development agendas, strategies and plans, at both national and international level. Precondition for maximization of the economic, social 
and other benefits of education is the coordination of education policy with other policies such as health, labour market, economic and others. Thus, the workforce capacity determines the country's ability to generate economic growth and development, mainly through channels such as skills development and skills improvement, innovations and others.

Human capital plays three very important and distinct roles: increasing wages for the individual who possess the human capital, facilitating the acquisition of human capital by the offspring by the individual with human capita and increasing the rate by which the economy acquires and implements new technologies. Thus, importance of human capital and education is undoubtable. However, due to constantly changing environment due to globalization, integration and knowledge - based societies, education as such faces many challenges. These challenges are shaping the entire education system today, including its institutions, teacher development, curriculums, teaching methods etc. Change and adapt the education system in order to serve its main purpose, i.e. enhancement and creation of human capital that will lead to overall economic growth and development. Economic and social functions place education in the centre of both processes. Furthermore, to fulfil these functions education policy creators, researchers and practitioners have to take into account the global trends that are changing educational patterns. These trends are economic, social, technological and demographical. Globalization, high levels of integration and multidisciplinary character of education are forcing the education policy creators to cooperation and coordination with other decision makers.

Lack of cooperation and coordination in most cases results in skills mismatch. This is a serious issue for transitional developing economies including the countries from the Western Balkans region. Such case in these economies is often associated with the low quality of education at all levels (primary, secondary and higher education) as well as the minor levels of public expenditure resulting in a condensed number of available skilled workers (Sondergaard, Murthi, 2012). The reconstruction of these economies through the privatization and liberalization process has resulted in vanishing of numerous jobs (Arandarenko, Bartlett, 2012) but parallel to this, emergence of new technologies, knowledge based economies and competitive global market has created a demand for updated education system that will enable the acquisition of new knowledge and skills for $21^{\text {st }}$ labour market.

This paper employs the USAID MEASURE-BiH National Youth Survey (NYS) data set in the analysis of the relationship between education and employment and it attempts to find the answers on the following research questions:

RQ1: What is the effect of education on the employment perspectives of Bosnia and Herzegovina's youth?

RQ2: Is there a difference between the effects of formal and non - formal education on the employment perspectives of Bosnia and Herzegovina's youth?

The main objective of this paper is to examine the effect of different forms of education on the employment of Bosnia and Herzegovina's youth. Thus, this paper contributes to the existing scientific literature that deals with transitional context of employment and education relationship. It also provides several practical implications of such research design. The paper is organised as follows: after introduction, the theoretical framework identifies different forms of education and its contribution to various economic and social aspects. The detailed explanation of data set used, model and its estimation is provided in the third part of the paper. This is followed by the presentation of results and the discussion. Concluding remarks, recommendations and bibliography are provided at the end of the paper. 


\section{Hypothesis development}

Wider understanding of education today differs in many aspects: availability or access to education, teaching methods used, content or what is being thought and lastly, the philosophy behind the entire idea of education is different. However, today's understanding of economic growth and development processes gives education a central role.

Education today takes various forms, where most common are formal and non formal education. Thus, for the purpose of analysis in this paper we employ the following definitions of these two forms of education. Formal education both, private and public has institutional framework and it is intentional and planned. Programs in this form of education are recognized as such by relevant national educational authorities or equivalent. Formal education system is in most cases based on the initial education, however, special needs and adult education are often parts of the system. In addition, non-formal education is considered a complement to a formal education within the process of lifelong learning. This form of education may be organized for a short time period and/or with lower intensity and in different formats (short courses, seminars, workshops). Non - formal education in most cases ends with qualifications that are not recognized as formal qualifications provided by the relevant national educational institutions or to no qualification at all. This form of education usually contributes to adult and youth literacy and education for out-of-school children, programs on life skills, work skills, social and cultural development and others (UNESCO, ISCED, 2011). Another form that concerned is the informal learning, which is not formally organised, with no clearly set objectives in form of learning outcomes. Informal learning is not intentional learning and it is often referred as experience and/or learning by experience (Werquin, 2007).

One of the biggest challenges that youth faces today is education to employment path, often called transition from school to work. Education has been recognized as an important factor of personal development as well as country's growth and development. Holistic approach in education analysis is important and needed due to its multiple importance. One of the key relationship is the one between education and labour market. Labour markets are also changing mostly due to the change in demand for specific knowledge and skills caused by the changes in the essence and nature of work and jobs in highly competitive knowledge - based societies. Thus, longterm goal in every education agenda should be to improve education in such way that will raise the employability of the workforce, in particular youth population since they are one of the most vulnerable social groups. However, if the education system per se does not raise the employability, unemployment raises due to education and skills mismatch.

Skills mismatch refers to various types of imbalances between skills, knowledge and competences acquired and those needed and demanded on the labour market. This mismatch is often regarded as the gap between students' knowledge and skills and employer expectations and it is widening over time (Bailey, Mitchell, 2006, McGuinness, Sloane, 2011). Consequences of mismatch of worker's education and job educational requirements have been analysed in the literature. Mismatch in formal education is often referred as educational mismatch. Consequences of mismatch between worker's formal education and their jobs educational requirements is mostly referred in the literature as wage penalty (Lamo et al., 2010, Baver, 2002, McGuinness, Sloane, 2011, McGuinness, 2006 and others). Lamo et al. (2010) state that all studies show wage penalties and over education phenomenon as a consequence of this mismatch while McGuinness (2006) show 15\% lower wages on average in case of over education. Education mismatch can be a temporary or 
permanent situation, where temporary mismatch refers to career mobility or career change (Jovanovic, 1979, Sicherman, Galor, 1990) or a permanent case (Dolado et al., 2008). It can also be caused by the problems on the demand side (Green, Zhu, 2010, Melink, Pavlin, 2012), specifically by the decline on the demand side or stagnation of labor market side (Fink-Hafner, Dezelan, 2011), or by the problems on the supply, side such as an increase in the number of graduates (Teichler, 2009) or expansion of tertiary education (Green, Zhu, 2010).

\section{Literature review}

The human capital theory promotes the idea that education is the main instrument through which individuals acquire their skills and capacities (Dezelan et al., 2014). On the other side, employers see education as a factor of productivity and trainability of future workers (Garcia-Espejo, Ibanez, 2006). Stenberg et al. (2014) have shown the existence of positive effects of formal education on wage levels especially for women and women and children. Thus, following two hypothesis have been tested:

-H1: Level of formal education is positively related to Bosnia and Herzegovina's youth employment status.

Non - formal education is becoming an important factor in mitigating the negative effects of skills mismatch since formal education is adopting too slowly to all changes in the world. Various positive effects of non-formal education at different levels have been previously observed in Rata et al. (2014) when observing the effectiveness of non-formal education at the middle school levels, while Abdullai et al. (2012) state that informal education is a tool for skills mismatch minimizing. Cairo and Cajner (2013) argue that on-the-job training complements to formal education and that as such improves employment stability especially within the more educated workers. Li and Liu (2010) argue that specific entrepreneurship education has a positive effect on employment possibilities. Otero (2016) also argues that non - formal education acquired through youth organisations has positive effects on various forms of capital (human, social and psychological) as well on the future youth employability. Based on the previous research, the following hypothesis has been proposed:

-H2: Non-formal education is positively related to Bosnia and Herzegovina's youth employment status.

Young people today are growing up in a world that is quite different from that of their parents. Patterns of learning and teaching are changing and education system has to anticipate and act accordingly to meet these changes. Education system is changing thus, formal and non-formal education complement each other and only the coordination of all forms of education will maximize the benefits of education.

\section{Research method}

\section{Sample and data collection}

By using USAID MEASURE-BiH National Youth Survey (NYS) data set this study analyses the role of education (both formal and in formal) in youth employment in Bosnia and Herzegovina. The data were collected using a survey questionnaire comprised 11 sections such as household and basic demographic information, formal and nonformal education, employment, etc. The data collection took place in the period January-February 2018. Total sample consists of 4.500 randomly selected respondents between 15 and 44 years of age. Participation in the survey was voluntary and anonymous. SPSS 22 software was used in the empirical analysis. Also, $20 \%$ of the data was rechecked to assess its accuracy and consistency. 


\section{Model}

Research model assumes that unemployment will be predicted by level of formal education, level of non-formal education, post-formal education period and ownership of the attended institutions. The independent variables in the model are:

Table 1 Independent variables

\begin{tabular}{|c|c|c|c|}
\hline $\begin{array}{c}\text { Name of } \\
\text { variable and } \\
\text { code }\end{array}$ & Description & Type & $\begin{array}{l}\text { Categories and } \\
\text { equation label }\end{array}$ \\
\hline $\begin{array}{l}\text { Level of } \\
\text { formal } \\
\text { education } \\
\text { L.F.EDU }\end{array}$ & $\begin{array}{l}\text { Derived from the question in the survey } \\
\text { related to the highest level of education } \\
\text { respondents completed }\end{array}$ & Categorical & $\begin{array}{l}\text {-Elementary school or } \\
\text { less (b1.1) } \\
\text {-Secondary school, 3- } \\
\text { year program (b1.2) } \\
\text {-Secondary school, 4- } \\
\text { year program (b } 1.3 \text { ) } \\
\text {-University education }\end{array}$ \\
\hline $\begin{array}{l}\text { Participation } \\
\text { in non-formal } \\
\text { education } \\
\text { and type of } \\
\text { non-formal } \\
\text { education } \\
\text { DUR.EDU }\end{array}$ & $\begin{array}{l}\text { Were assessed by two scales in the survey } \\
\text { based on available and legally regulated } \\
\text { forms of non-formal education in } \mathrm{BlH} \text {. }\end{array}$ & Categorical & $\begin{array}{l}\text {-Work experience } \\
\text { through internship } \\
\text { (b2.1) } \\
\text {-Work experience } \\
\text { through volunteering } \\
\text { (b2.2) } \\
\text {-Work experience } \\
\text { through paid jobs other } \\
\text { than internships or } \\
\text { volunteering (b2.3) } \\
\text {-Short courses/ extra- } \\
\text { curricular activities } \\
\text { (b2.4) } \\
\text {-None of the above }\end{array}$ \\
\hline $\begin{array}{l}\text { Post-formal } \\
\text { education } \\
\text { period N.EDU }\end{array}$ & $\begin{array}{l}\text { Was assessed as a number that indicates } \\
\text { how many years have passed since } \\
\text { highest-level education completion. It } \\
\text { was derived from the question: "When } \\
\text { did you complete your highest level of } \\
\text { education"? }\end{array}$ & Numerical & (b3) \\
\hline $\begin{array}{l}\text { Ownership of } \\
\text { educational } \\
\text { institution } \\
\text { F.P.EDU }\end{array}$ & $\begin{array}{l}\text { Was derived from the question: "Have } \\
\text { you ever attended or are you currently } \\
\text { attending a private school at any of the } \\
\text { following levels: } 1 \text {. No; } 2 \text {. Yes, private } \\
\text { primary school; } 3 \text {. Yes, private secondary } \\
\text { school; } 4 \text {. Yes, private university". } \\
\text { Classification of educational institution as } \\
\text { public or private was made in line with } \\
\text { OECD/EUROSTAT Data collection on } \\
\text { education statistics } 2012 \text {. An education } \\
\text { institution is can be classified as public } \\
\text { when it is under control and managed by } \\
\text { some type of public education authority } \\
\text { (agency). Private education institution is } \\
\text { managed and controlled by a non - } \\
\text { governmental organization. }\end{array}$ & Categorical & $\begin{array}{l}\text {-Public (b4) } \\
\text {-Private }\end{array}$ \\
\hline
\end{tabular}

The dependent variable included in the model is defined in Table 2. 
Table 2 Dependent variable

\begin{tabular}{|l|l|l|l|}
\hline $\begin{array}{c}\text { Name of } \\
\text { variable }\end{array}$ & \multicolumn{1}{|c|}{ Description } & Type & $\begin{array}{c}\text { Categories and } \\
\text { equation label }\end{array}$ \\
\hline $\begin{array}{l}\text { Employment } \\
\text { status }\end{array}$ & $\begin{array}{l}\text { Was derived from the relevant } \\
\text { questionnaire item: "What is your } \\
\text { employment status?" }\end{array}$ & Categorical & $\begin{array}{l}\text {-Employed (0) } \\
\text {-Unemployed (1) }\end{array}$ \\
\hline
\end{tabular}

Logistic regression model equation is as follows:

$$
\ln \left(\frac{\mathrm{p}}{1-\mathrm{p}}\right)=\mathrm{b} 0+\mathrm{b} 1.1 * \mathrm{x} 1.1+\mathrm{b} 1.2 * \mathrm{x} 1.2+\mathrm{b} 1.3 * \mathrm{x} 1.3+\mathrm{b} 2.1 * \mathrm{x} 2.1+
$$

$\mathrm{b} 2.2 * \mathrm{x} 2.2+\mathrm{b} 2.3 * \mathrm{x} 2.3+\mathrm{b} 2.4 * \mathrm{x} 2.4+\mathrm{b} 3 * \mathrm{x} 3+\mathrm{b} 4 * \mathrm{x} 4$, where b0 means the intercept, with the other logistic regression parameters defined, as it is given in Table 1, and the $p$ means probability, as follows:

$$
\mathrm{p}=\frac{1}{1+\mathrm{e}^{-\mathrm{y}^{\prime}}}
$$

where y means predicted probability of being unemployed while $y^{\prime}$ means actual probability of an individual being unemployed.

\section{Research results}

To test the hypotheses, we used logistic regression analyses procedures using SPSS version 22 (logit link function). Our model assumes that participation into non-formal education (N.EDU), type of non-formal education (N.EDU.Type), level of formal education (L.F.EDU), ownership of formal education institution (F.P.EDU) and duration of formal education (DUR.EDU) are significant predictors of employment status. Without any predictor in the model, $63.9 \%$ of cases would be correctly classified as employed or unemployed. Specifically, there is statistically significant difference in number of respondents being employed and unemployed (Wald=331; $d f=1 ; p<0.001$ ). There is 1.77 greater likelihood that someone is unemployed comparing to not being employed.

Therefore, first we conducted Omnibus test, which shows that the model is having predictive capacity (Appendix 1; Table 1). The model successfully explains about $27 \%$ of employment status (based on pseudo Nagelkerke R Square). Then, we applied Hosmer and Lemeshow Test (Appendix 1; Table 2) which indicates that there is a statistically significant difference between envisaged model and observed covariance structure. This is expected, as number of respondents is large lover 4000 respondents).

Predictive model improves classification of respondents on employed and unemployed for about $4.1 \%$, reaching correct predictions for $68.9 \%$ of respondents.

Most of changes in independent variables have statistically significant effect on the change in dependent variables, controlling for other independent variables.

Respondents who would retain low level of formal education (elementary school or less) comparing to others levels of formal education (secondary school or university), would have about 39 times higher likelihood of being unemployed comparing to those with other level of formal education. Expected change is statistically significant.

Respondents who would retain at the secondary school level (3-year program) comparing to others levels of formal education (elementary school or less, secondary school 4-year program and university level), would have about 3 times higher likelihood of being unemployed comparing to those with other level of formal education. Expected change is statistically significant. 
Respondents who would retain at the secondary school level (4- year program) comparing to others levels of formal education (elementary school or less, secondary school 3-year program and university level), would have also about 3 times higher likelihood of being unemployed comparing to those with other level of formal education. Expected change is statistically significant.

For the increase of one year in post-formal education period there is a decrease of $6 \%$ in likelihood for respondents to be unemployed. If someone would participate in non-formal education through internship programme, comparing to other types of non-formal programs (volunteering, paid job, extra-curricular activities or no nonformal education at all) it would decrease likelihood of being unemployed for about $28 \%$. If someone would participate in non-formal education through paid jobs other than internships or volunteering, comparing to other types of non-formal programs (internship, volunteering, extra-curricular activities or no non-formal education at all) it would decrease likelihood of being unemployed for about $60 \%$. Other changes in independent variables would not be reflects in statistically significant change in employment status.

Table 3 Variables in the Equation

\begin{tabular}{|c|c|c|c|c|c|c|}
\hline Variables & B & S.E. & Wald & $\mathrm{df}$ & Sig. & $\operatorname{Exp}(B)$ \\
\hline Level of formal education & & & 400.085 & 3 & .000 & \\
\hline Elementary school or less & 3.655 & 185 & 389.249 & 1 & .000 & 38.684 \\
\hline $\begin{array}{l}\text { Secondary school, 3-year } \\
\text { program }\end{array}$ & 1.007 & .119 & 71.480 & 1 & .000 & 2.737 \\
\hline $\begin{array}{l}\text { Secondary school, 4-year } \\
\text { program }\end{array}$ & 1.160 & 102 & 128.360 & 1 & .000 & 3.191 \\
\hline Post-formal education period & -.062 & .005 & 178.488 & 1 & .000 & .940 \\
\hline Type of non-formal education & & & 39.974 & 4 & .000 & \\
\hline $\begin{array}{l}\text { Non-formal education } \\
\text { through internship }\end{array}$ & -.333 & 095 & 12.261 & 1 & .000 & 717 \\
\hline $\begin{array}{l}\text { Non-formal education } \\
\text { through volunteering }\end{array}$ & -.115 & 160 & .513 & 1 & 474 & .892 \\
\hline $\begin{array}{l}\text { Non-formal education } \\
\text { through paid jobs }\end{array}$ & -.928 & 160 & 33.715 & 1 & .000 & .395 \\
\hline $\begin{array}{l}\text { Non-formal education } \\
\text { through short courses/extra- } \\
\text { curricular activities }\end{array}$ & -.190 & 119 & 2.568 & 1 & 109 & .827 \\
\hline $\begin{array}{l}\text { Participation in non-formal } \\
\text { education }\end{array}$ & .060 & .111 & .298 & 1 & .585 & 1.062 \\
\hline $\begin{array}{l}\text { Ownership of educational } \\
\text { institution }\end{array}$ & 185 & 192 & .929 & 1 & .335 & 1.204 \\
\hline Constant & -.090 & .204 & 193 & 1 & .660 & .914 \\
\hline
\end{tabular}

Note a: Coding and labelling of categorical variables see Appendix 2.

Note b: Variable(s) entered on step 1: L.F.EDU, DUR.EDU, F.P.EDU, N.EDU, N.EDU.Type.

\section{Discussion}

The results of our logistic regression analyses on USAID MEASURE-BiH National Youth Survey (NYS) data set supported our hypotheses. It first revealed that level of formal education is positively related to youth employment in Bosnia and Herzegovina. Formal education programmes are expected to make young people more employable (Garcia-Espejo, Ibanez, 2006, Rata et al., 2014).

Moreover, it is found that young people who have completed their highest level of education recently are more likely to be unemployed. We assume this is due to the 
lack of work experience or even non-formal learning experience (in line with second hypothesis) compared to those young people who had earned formal education qualifications many years earlier.

Finally, the positive link between non-formal education and youth employment is supported as our results showed that different types of paid jobs as a part of education process (learning by doing) but also internships or volunteering significantly contribute to youth employability (Abdullai et al., 2012, Cairo, Cajner, 2013, Otero, 2016).

A model that combines formal and non-formal education aiming to address youth employability in Bosnia and Herzegovina was defined and tested empirically in this study. Although, the relationship between (in) formal education and employment has been investigated for decades, this important relationship in transitional context still remains unexplored. Our choice of the context makes our study even more significant for few important reasons. Namely, transition from centrally planned to market economy on one side, and war and post war migrations on the other side have resulted in serious labour market and education system disturbances. Educational system is predominantly public and defined by an overall governance structure without adequate support for "school- to-work" transition including non-formal education programs.

Defined model makes a significant contribution to the contemporary literature, especially when it comes to transitional context providing very important insights into challenges and youth employment opportunities beyond well-researched Western economies. To our best knowledge, education and labour market relationship in case of transition economies has not been in focus of the contemporary scientific literature and thus this research provides a contribution to filling in this gap. Different reforms of both, education and labour market systems in these countries have been implemented however, the examination of their impact (positive and negative) on these economics has not been investigated. Thus, this research is a contribution to this literature since it analyses the impact of education on youth employability in a country, which is still considered to be in the transition process.

This research also provides useful practical implications. First, we show that young people who completed highest level of formal education and participated in nonformal education through internship programmes, volunteering and other non-formal education programs are more likely to be employed. In addition, the results of the study could be very useful for national employment policymakers in terms of achieving country's employment goals through design of fitting policy instruments. The policy makers are advised to work on consistency of the elements of the relevant policy mixes for sustainable youth employment programmes particularly those involved in addressing non-formal education challenges and their legally unrecognized status. The paper suggests that investments in education, both formal and non-formal programs, including relevant curriculum development and improvements, need to be made based on those insights enhancing youth employability in one small transition country.

\section{Conclusion}

This study found that formal education and non-formal education through internship programmes, volunteering, paid jobs other than internships represent significant predictors of youth employment status. The study has several implications for academics and practitioners by providing new insights into both employment patterns and practices in one transition economy.

However, our approach has limitations. The most important one relates to the use of secondary data (the USAID MEASURE-BiH National Youth Survey (NYS) data set), so 
we could not revise or change questionnaire content. This strongly affected our research model and choice of variables. Secondly, the scope of the study included young population in transitional context and results should not be generalized to developed countries. However, certain limitations create possibilities for future research.

Our results call for unpacking the link between education (formal and non-formal) and youth employment. We suggest strongly contextualized perspective in developing youth employment practices through relevant formal and non-formal education programmes. Further research is necessary to understand this interrelation. A more detailed analysis of available education programmes in terms of their labour market relevance and vocational orientation, their development over time and their impact on youth employment should be conducted. We argue that this analysis is the first step towards examining role of education in youth employability in very specific context. Finally, our approach is very proxy way for suggesting specific policy instruments. Therefore, further empirical research including policy mix approach may sharpen policy advice in the context of youth employment in $\mathrm{BIH}$. Our aim was to broaden discussion about the importance of education for youth employability and thus tackle policy challenges.

\section{References}

1. Abdullai, J., Tresi, A., Ramadani, K. (2012). Non-formal education a tool for reducing the transition obstacles. Procedia - Social and Behavioural Sciences, Vol. 46, pp. 4923-4927.

2. Arandarenko, M., Bartlett, W. (2012). Labor market and skills in the Western Balkans. FREN Foundation for the Advancement of Economics, Belgrade.

3. Bailey, J., Mitchell, R. B. (2006). Industry perception of the competences needed by computer programmers: technical, business and soft skills. Journal of Computer Information Systems, Vol. 47, No. 2, pp. 28-33.

4. Baver, T. (2002). Educational mismatch and wages: A panel analysis. Economics of Education Review, Vol. 21, No. 3, pp. 221-229.

5. Cairo, I., Cajner, T. (2013). Human Capital and Unemployment Dynamics: Why More Educated Workers Enjoy Greater Employment Stability. Available at https://ssrn.com/abstract=2976898 [10 July 2018].

6. Dezelan, T., Fink-Hafner, D., Melink, M. (2014). First-job educational and skill match: An empirical investigation of political science graduates in Slovenia. International Journal of Manpower, Vol. 35, No. 4, pp. 553-575.

7. Dolado, P., Jansen, J., Aimeno, J. F. (2008). On the job search in a matching model with heterogeneous jobs and workers. Economic Journal, Vol. 119, No. 534, pp. 200-228.

8. Fink-Hafner, D., Dezelan, T. (2011). The political scientist: a profession in decline? Available at $\quad \mathrm{http} / / / \mathrm{www}$.dehems-project.eu/static/uploaded/files/files/contributions/FinkHafner_Danica_DEHEMS_Conference_Paper_The_Political_Scientist_A_profession_in_Decli ne.pdf [26 July 2018].

9. Garcia-Espejo, I., Ibanez, M. (2006). Educational-skill matches and labour achievements among graduates in Spain. European Sociological Review, Vol. 2, No. 2, pp. 141-156.

10. Green, F., Zhu, Y. (2010). Overqualification, job satisfaction, and increasing dispersion in the returns to graduate education. Oxford Economic Papers, Vol. 62, No. 4, pp. 1-24.

11. Jovanovic, B. (1979). Job matching and the theory of turnover. Journal of Political Economy, Vol. 87, No. 5, pp. 972-990.

12. Lamo, A., Messina, J., Wasmer, E. (2010). Are specific skills an obstacle to labour market adjustment? Available at https://d-nb.info/100816867X/34 [10 July 2018].

13. Li, Z., Liu, Y. (2010). Entrepreneurship education and employment performance. Journal of Chinese Entrepreneurship, Vol. 3, No. 3, pp. 195-203.

14. McGuinness, S. (2006). Overeducation in the labour market. Journal of Economic Surveys, Vol. 20, No. 3, pp. 387-418. 
15. McGuinness, S., Sloane, P. J. (2011). Labour market mismatch among UK graduates: an analysis using REXLEX data. Economics of Education Review, Vol. 30, No. 1, pp. 130-145.

16. Melink, M., Pavlin, S. (Eds.) (2012). Employability of Graduates and Higher Education Management Systems. Available at http://www.dehemsproject.eu/static/uploaded/files/files/resoults/AttK1_DEHEMS_final_rep ort.pdf [26 July 2018].

17. Otero, S. M. (2016). Young people's views of the outcome of non - formal education in youth organisations: its effects on human, social and psychological capital, employability and employment. Journal of youth studies, Vol. 19, No. 7, pp. 938-956.

18. Rata, G., Dobrescu, T., Rata, B. C., Rata, M. (2014). The effectiveness of non-formal education in improving the effort capacity in middle-school pupils. Procedia-Social and Behavioral Sciences, Vol. 116, pp. 2722-2726.

19. Sicherman, N., Galor, O. (1990). A theory of career mobility. Journal of Political Economy, Vol. 98, No. 1, pp. 169-192.

20. Sondergaard, L., Murthi, M. (2012). Skills, Not Just Diplomas, Managing Education for Results in Eastern Europe and Central Asia. World Bank, Washington D.C.

21. Stenberg, A. Xavier de L., Westerlund, O. (2014). Does Formal Education for Older Workers Increase Earnings? - Evidence Based on Rich Data and Long - term Follow-up. Labour, Vol. 28, No. 2, pp. 163-189.

22. Teichler, U. (2009). Higher Education and the World of Work: Conceptual Frameworks, Comparative Perspectives, Empirical Findings. Sense Publisher, Rotterdam, Taipei.

23. UNESCO, ISCED (2011). Formal education. Available at http://vis.unesco.org/node/334633 [10 July 2018].

24. Werquin, P. (2007). Terms, concepts and models for analysing the value of recognition programmes. Available at http://www.oecd.org/education/skills-beyondschool/41834711.pdf [10 July 2018].

\section{About the authors}

Amila Pilav - Velić, PhD, is an assistant professor at the Department of Management and Information Technology, School of Economics and Business, University of Sarajevo. She completed postdoctoral studies at Chair for Innovation Management, Freie Universität Berlin. Her main areas of expertise include innovation management, particularly open innovation, business process management (innovations) and inter-organizational collaboration. As a pioneer of open innovation in her country, she has participated in many relevant projects including consultancy in the field. In addition, she has considerable knowledge and extensive experience in the EU funding programmes and projects. Amila Pilav - Velić is the author of numerous research papers, including one chapter and a book. In 2013, she was appointed the Head of Faculty Development Centre at her home institution. She can be contacted at amila.pilav-velic@efsa.unsa.ba.

Hatidža Jahić, PhD, is an assistant professor at the Department of Economic Theory and Policy, School of Economics and Business, University of Sarajevo, Bosnia and Herzegovina. Her fields of interests include education economics, development economics and international economics. She is the author of numerous papers presented at conferences and published in domestic and international journals. She has participated in several domestic and international projects. The author can be contacted at hatidza.jahic@efsa.unsa.ba.

Jasmina Okičić, PhD, is an associate professor in the field of quantitative economics at the Faculty of Economics of the University of Tuzla, Bosnia and Herzegovina. Her research interests include research methods, quantitative finance and econometrics. As the author and coauthor, she published two university textbooks and is the author of numerous scientific and professional papers published in international journals and conference proceedings. She has participated in several local and international projects. The author can be contacted at jasmina.okicic@untz.ba. 
Meldina Kokorović - Jukan, $\mathrm{PhD}$, is an associate professor at the Department of Finance and Financial Policy at the Faculty of Economics, University of Tuzla, Bosnia and Herzegovina. Her academic career is more than 12 years long. Her main academic and professional interests are related to management of financial institutions, corporate financial management, monetary and fiscal policy as well as project monitoring and impact evaluation. She authored and co-authored 2 books and over 40 scientific and research papers published nationally and internationally. She has mentored and supervised several master theses, and her work includes regular involvement in the evaluation of postgraduate research as well as doctoral dissertations. She was a visiting scholar in 2009 at the George Washington School of Business, George Washington University, Washington DC USA. She holds a Certificate in Evaluation Practice from the Evaluators' Institute at Claremont Graduate University, Claremont, CA, USA. She can be contacted at meldina.kokorovic@untz.ba. 


\section{Appendix 1}

Table Al Omnibus Tests of Model Coefficients

\begin{tabular}{|c|l|c|c|c|}
\hline \multicolumn{2}{|c|}{} & Chi-square & df & Sig. \\
\hline \multirow{3}{*}{ Step 1} & Step & 959.442 & 10 & .000 \\
\cline { 2 - 5 } & Block & 959.442 & 10 & .000 \\
\cline { 2 - 5 } & Model & 959.442 & 10 & .000 \\
\hline
\end{tabular}

Table A2 Model summary

\begin{tabular}{|c|c|c|c|}
\hline Step & -2 Log likelihood & $\begin{array}{c}\text { Cox \& Snell } R \\
\text { Square }\end{array}$ & Nagelkerke R Square \\
\hline 1 & $4833.111^{a}$ & .195 & .267 \\
\hline
\end{tabular}

Note: a. Estimation terminated at iteration number 6 because parameter estimates changed by less than .001 .

Table A3 Hosmer and Lemeshow Test

\begin{tabular}{|c|c|c|c|}
\hline Step & Chi-square & df & Sig. \\
\hline 1 & 58.272 & 8 & .000 \\
\hline
\end{tabular}

Table A4 Classification Tablea

\begin{tabular}{|l|c|c|c|c|}
\hline \multirow{2}{*}{ Observed } & \multicolumn{3}{|c|}{ Predicted } & \multirow{2}{*}{ Percentage } \\
\cline { 3 - 4 } \multicolumn{2}{|c|}{} & Employed & Unemployed & \\
\cline { 3 - 4 } EMP & Employed & 767 & 833 & 47.9 \\
\cline { 2 - 4 } & Unemployed & 563 & 2264 & 80.1 \\
\hline \multicolumn{2}{|l|}{ Overall Percentage } & & & 68.5 \\
\hline \multicolumn{2}{|l|}{ a. The cut value is .500 } \\
\hline
\end{tabular}

\section{Appendix 2}

Table A5 Categorical Variables Codings

\begin{tabular}{|c|c|c|c|c|c|c|}
\hline & & \multirow{2}{*}{ Frequency } & \multicolumn{4}{|c|}{ Parameter coding } \\
\hline & & & (1) & $(2)$ & (3) & (4) \\
\hline \multirow[t]{5}{*}{ N.EDU.Type } & Work experience through internship & 795 & 1.000 & .000 & .000 & .000 \\
\hline & Work experience through volunteering & 229 & .000 & 1.000 & .000 & .000 \\
\hline & $\begin{array}{l}\text { Work experience through paid jobs other } \\
\text { than internships or volunteering }\end{array}$ & 213 & .000 & .000 & 1.000 & .000 \\
\hline & Short courses/extra-curricular activities & 591 & .000 & .000 & .000 & 1.000 \\
\hline & None of the above & 2599 & .000 & .000 & .000 & .000 \\
\hline \multirow[t]{4}{*}{ L.F.EDU } & Elementary school or less & 930 & 1.000 & .000 & .000 & \\
\hline & Secondary school, 3-year program & 917 & .000 & 1.000 & .000 & \\
\hline & Secondary school, 4-year program & 1984 & .000 & .000 & 1.000 & \\
\hline & University education & 596 & .000 & .000 & .000 & \\
\hline \multirow[t]{2}{*}{ N.EDU } & Yes & 667 & 1.000 & & & \\
\hline & No & 3760 & .000 & & & \\
\hline \multirow[t]{2}{*}{ F.P.EDU } & Only public education institution & 4294 & 1.000 & & & \\
\hline & Some private education institution & 133 & .000 & & & \\
\hline
\end{tabular}

Note: Unemployed group of young people was labelled by 1. 